\title{
Angels and demons, innocents and penitents: An analysis of different "characters" within the penal discourse of apartheid South Africa 1980 to 1984 - Part One
}

\author{
Stephen Allister Peté \\ $B A L L B$ LLM M Phil \\ Associate Professor, School of Law, Howard College Campus, University of KwaZulu- \\ Natal \\ Attorney of the High Court of South Africa
}

\section{OPSOMMING}

Engele en Duiwels, Onskuldiges en Boete-doeners: 'n Analise van Verskillende "Karakters" in die Gevangenis-diskoers van Apartheid Suid-Afrika (1980 tot 1984)

\begin{abstract}
Wat ras, klas en geslag betref was daar vanaf koloniale tye af nog altyd ' $n$ tweespalt in die Suid-Afrikaanse gemeenskap. In so 'n verskeurde samelewing is die openbare debat rondom 'n komplekse sosiale praktyk soos straf of gevangenisskap noodwendig deurspek met nuanse. Hierdie artikel ondersoek wyses waarop temas in die openbare debat rondom gevangenisskap in Suid-Afrika verskil van een kategorie van gevangenes tot die volgende. Die tydperk wat ondersoek word is die eerste helfte van die 1980 s - 'n dekade waarin aansienlike krake in apartheid toegedien is; 'n tydperk waarin interne en eksterne opposisie teen die stelsel 'n hoogtepunt bereik het, en die owerhede met 'n "algehele strategie" opgetree het. Elke draad van die ondersoekte diskoers onthul 'n ander "karakter" in die oorkoepelende verhaal wat spruit uit die gevangenisdiskoers van die tyd. Die diskoers rondom die volgende vier kategorieë van gevangenes word ondersoek: wit manlike gevangenes, bende-lede in gevangenis, wit vroulike gevangenes, kinders. Die artikel bestaan uit twee dele - Deel Een fokus op die eerste twee kategorieë en Deel Twee op die laaste twee.
\end{abstract}

\section{Introduction}

In general terms, public discourse surrounding imprisonment as a form of punishment is multi-layered and nuanced. It is influenced by the social, political and economic history of the penal system under discussion, as well as by the particular historical conjuncture at which the discourse is examined. Furthermore, penal discourse will often vary widely from one category of prisoners to the next. The complex and multivalent nature of such discourse is particularly apparent in the case of the South African penal system, perhaps because of the deeply divided nature of South African society from colonial times to the present. The

How to cite: Peté 'Angels and demons, innocents and penitents: An analysis of different "characters" within the 
purpose of this article is to examine the ways in which, at a particularly crucial time in the country's history, strands in the public discourse surrounding imprisonment in South Africa differed from one category of prisoners to the next. Each strand reveals a different "character" within the overall story which emerges from the penal discourse of the time.

The period examined is the first half of the 1980s, a decade which witnessed major cracks in apartheid, as internal and external opposition to the system reached a climax and the authorities responded with their so-called "total strategy". The total strategy of the apartheid government included the further militarisation of an already militarised white South African society, as well as the declaration of a state of emergency on 20 July 1985. The first half of the 1980s is particularly interesting from the point of view of penal discourse since the prisons were one of the points at which the stresses and strains within the apartheid system became visible, despite efforts on the part of the authorities to stifle reporting in the press. ${ }^{1}$ The focus of this article is on a cross-section of reports drawn from national and regional newspapers published during this time, including both the English and Afrikaans "white mainstream press", 2 the more "politically conservative Afrikaner press"; 3 and the "black mainstream press". ${ }^{4}$ By comparing and contrasting many reports from these sources, it is possible to extract a fairly clear overall picture of the public discourse surrounding imprisonment at this time.

The discourse surrounding the following categories of prisoners is examined: white male prisoners; prison gang members; white female prisoners; and children. The first two categories will be dealt with in Part One of this article, and the last two categories in Part Two. The reasons for choosing to examine these particular categories of prisoners are: firstly, each of these categories is clearly distinguishable in the data as giving rise to a separate strand of discourse; secondly, the categories are sufficiently distinct from each other to provide clear points of contrast, sometimes appearing as polar opposites within the penal discourse as a whole; and thirdly, for each of the categories there are historical parallels

1 See in general, Peté 'Holding up a mirror to apartheid South Africa - Public discourse on the issue of overcrowding in South African prisons 1980 to 1984 - Parts one and two' (forthcoming).

2 In this article the term "white mainstream press" is used as a rough rule of thumb and should not be read as a strict scientific definition. In this article, the English white mainstream press is taken to include newspapers such as the Cape Times, the Rand Daily Mail, the Natal Mercury, the Natal Witness, the Daily News, the Cape Times, The Star, the Eastern Province Herald, the Sunday Tribune and the Daily Dispatch. The Afrikaans white mainstream press is taken to include newspapers such as Beeld and Rapport.

3 In this article, the term "more politically conservative Afrikaner press" is used as a rough rule of thumb and should not be read as a strict scientific definition. In this article, the more politically conservative Afrikaner press is taken to include newspapers such as Die Volksblad and Die Vaderland.

4 In this article the term "mainstream black press" is used as a rough rule of thumb and should not be read as a strict scientific definition. In this article the mainstream black press is taken to include newspapers such as City Press and Sowetan. 
to be drawn - historical resonances - with strands of discourse which emerged long before during colonial times. In relation to the historical parallels which may be drawn, it is clearly beyond the scope of this article to capture every nuance of South African penal discourse over several centuries, in order to identify each possible point of convergence within the discourse. Instead, this article will focus particularly on the penal discourse of colonial Natal for purposes of comparison. A defined focus of this kind allows a deeper and more nuanced analysis and comparison of penal discourse than would otherwise be possible.

Public discourse is important since it provides a clear indication of the ideological context within which the punishment of prisoners is taking place. A detailed understanding of this ideological context will, it is submitted, be helpful in getting to grips with the dilemmas faced by the South African penal system today. While problems such as overcrowding, "warehousing", racial discrimination, the continued existence of prison gangs, the general failure to rehabilitate offenders, and so on, are often discussed in practical terms, the ideological dimension of the general failure of our penal system is not often addressed. Why is it that the same "problems" and the same "solutions" are endlessly, but fruitlessly, debated from year to year, decade to decade, and from one century to the next? In separating out the strands of public discourse in respect of different categories of prisoners in apartheid South Africa during the first half of the 1980s, and linking these strands to previous debates during colonial times, this article hopes to make progress towards answering this question and to contribute to a deeper understanding of the ideological context of imprisonment in South Africa.

\section{Penitents - White Male Prisoners}

As a starting point to an examination of the discourse surrounding the punishment of white male prisoners in the first half of the 1980s, it is useful to make brief mention of what I have termed "historical resonances" within this particular strand of penal discourse. As mentioned in the introduction, the penal system of colonial Natal will be used as a point of comparison. An established theme in the discourse surrounding punishment in Natal during the colonial period was that the punishment of white offenders should be approached in a different manner to the punishment of black offenders. ${ }^{5}$ Whereas the punishment of black offenders was often discussed in terms of retribution and the reestablishment of (white) authority and control, the discourse surrounding the punishment of white offenders was concerned mainly with rehabilitation and training. Corporal punishment with the dreaded cat-o-

5 For a detailed account of the different strands of discourse surrounding the punishment of white and black prisoners in colonial Natal, see Peté 'Punishment and Race: The Emergence of Racially Defined Punishment in Colonial Natal' 1986 Natal University Law and Society Review 99-114. 
nine-tails was considered a particularly suitable punishment for black "savages", whereas skills-training in an environment segregated from the "brutalising" world inhabited by black prisoners, was considered appropriate for white offenders. ${ }^{6}$ As stated in previous work by this author:

Although white prisoners formed only a small percentage of Natal's total prison population they assumed a symbolic importance as representatives of the white master class. The white colonists of Natal formed a small tightlyknit community and they perceived of themselves as the guardians of 'civilised' norms and standards in a savage and heathen country ... The closed, homogenous nature of white society meant that those who deviated from the norms of that society would be met with social ostracism ... The white prisoner did not only suffer the degradation of being branded as a criminal, however, but to this was added the humiliation of being confined alongside black prisoners and being subjected to the authority of black prison guards. There was thus a double stigma attached to imprisonment for a white person in Natal, and on leaving the prison the white ex-prisoner encountered extreme difficulty in obtaining employment as a result of this stigma. ${ }^{7}$

In an important public debate which took place in the Colony of Natal at the beginning of the twentieth century, the issue of white prisoners and their treatment was discussed. ${ }^{8}$ There was intense anxiety within white colonial society as to the perceived negative consequences of allowing "European" prisoners to be confined with prisoners of other races. For example, in January 1905 a correspondent to the Natal Advertiser expressed the following opinion:

Nothing is more keenly felt, nothing tends more to make a white man lose his self-respect in effecting reformation than to be paraded cheek by jowl several times a day with, and addressed in terms of familiarity by sombre tinted individuals, who in this part of the world only pass muster as 'Europeans' ...

The anxiety of white prisoners to avoid "contamination" by contact with prisoners of mixed race was, at times, paranoid in nature. This is well illustrated in the following laughable account by a white journalist who was confined in the Durban Gaol at the turn of the century:

[A] European in [Natal] ... outside of a prison, means a white man with no coloured blood in him. Inside a prison it means anybody with a nominal education and dressed something like a European ... [T] he idea of whites and blacks huddled together is, when you see it as I saw it in gaol, revolting ... Three in a little cell - think of it - with the same bucket to use as a latrine, the

6 See for example, Peté supra n 5 at 99-114; and Peté \& Devenish 'Flogging, Fear and Food: Punishment and Race in Colonial Natal' 2005 Journal of Southern African Studies 3-21.

$7 \quad$ Peté supra $n 5$ at $106 \& 107$

8 This debate took place during the deliberations of the Prison Reform Commission, between 1904 and 1906, when the final report of commission was delivered. See the Natal Government Gazette 1906-06-05 Government Notice 344: Report of the Prison Reform Commission.

9 Natal Advertiser (1905-01-05) 'Prison Reform' 
same blankets continually interchanged, the same filth, and insect life creeping and crawling from white to black and from black to white! ${ }^{10}$

The white colonists were worried about more than the perceived dangers of "contamination" and its effect on the rehabilitation of "European" prisoners. Mixing "European" prisoners with "Coloured" prisoners was regarded as posing an ideological threat to white sovereignty as a whole. This is well illustrated in the following extract from the Natal Advertiser:

The gaols in Maritzburg and Durban see some thousands of natives passing through every year, and they observe that you treat white men (whom they naturally regard as your brothers) on an absolute equality with Hottentots, Griquas, and other coloured races, whom they themselves regard as their inferiors. ${ }^{11}$

The Natal Prison Reform Commission, which delivered its report in June 1906, concluded that the most fitting solution to the particular dilemmas faced by "European" prisoners - the double stigma and the near impossibility of finding unskilled employment upon release - was the construction of an entirely separate prison focused on industrial skills training for "Europeans". ${ }^{12}$ Although this separate prison was never built, the ideology behind its proposed construction is clear. Within the proposed industrial prison for "Europeans", white prisoners would be reformed and taught industrial skills to enable them to fit in as members of the ruling white middle class upon their discharge. ${ }^{13}$ Furthermore, with white prisoners sequestered from the public gaze in their exclusive industrial prison, unnecessary threats to white sovereignty would be avoided.

Moving forward in time from the 1900s to the 1980s, it is significant that the theme of racially differentiated punishment which, as pointed out above, emerged particularly strongly during the late colonial period, is still present within penal discourse. Although, by the 1980s, South Africa was clearly a country in transition, this theme - harsh treatment of black offenders versus rehabilitation and training for white offenders - continued to assert itself. An examination of newspaper reports dealing with white prisoners and their treatment in the first half of the 1980s, reveals a completely different ideological and conceptual world to that which is presupposed when the treatment of "non-white" prisoners is being reported on. ${ }^{14}$ Although not all reports mention explicitly that it is "white" prisoners as opposed to "non-white" prisoners that are being discussed, by reading between the lines it soon becomes clear whether one is dealing with the smaller and more exclusive category of "white"

10 Hardy The Black Peril (exact date of publication unknown) 274-275.

11 Supran 10

12 See the Natal Government Gazette supra $\mathrm{n} 8$.

13 Peté supra $\mathrm{n} 5$ at 110.

14 In this context, the category of "white prisoners" should not be taken to include white political prisoners, who form a completely separate ideological and conceptual category of their own. 
prisoners, or with the much bigger category of "normal" - ie overwhelmingly "non-white" - prisoners. In the case of the latter group, imprisonment in apartheid South Africa during the early 1980s almost inevitably meant having to survive chronic overcrowding and brutal treatment. It also meant that many of those imprisoned were not criminals at all, but ordinary people caught in the net of legal social control measures designed to prop up the system of apartheid. Public discussion concerning such prisoners was characterised by wider political concerns; outrage at or support for the apartheid system and its methods of social control; concern over the levels of violence and brutality within the system; worries over the stability and ultimate sustainability of the system, and so on. ${ }^{15}$ In the case of "white" prisoners, the concerns expressed were quite different. The language in newspaper reports describing the "white" prison experience is filled with references to introspection, self-discipline, honest hard work, skills-training and rehabilitation. A good example is a series of articles which appeared in September 1980 in Die Volksblad. The experiences of white male prisoners in Kroonstad prison were described, inter alia, as follows:

At Kroonstad, in the prison for white men, a new day has begun. It is $05 \mathrm{~h} 00$ and it's another day, another un-ending round of self-examination and selfpity, discipline and silence, a re-examination of one's sense of value... At half past six, with the clang of tin plates and knives still in their ears and the sense of comfort afforded by full stomachs and the memory of warm bodies together around the dining tables, they stand in the first bleak rays of a winter morning with drawn faces, ready for the day's work which must help shape and prepare for a new life - one day ... Hands work with wood, weld, paint, bend and shape - for five hours. At half past eleven it is lunch time. At a central point hundreds of mouths swallow and chew eagerly at a meal of warm, nutritionally balanced food, smoke a precious cigarette, exchange desires and dreams... and then walk back to the work stations. Until half past four. Then it's the long, depressing road back to the prison ... Afterwards a chance for rest and relaxation. Competitive sport, measuring strength and skill, winning trophies and shields - or simply relaxing with a book, listening to music and trying to achieve inner peace within your restricted surroundings. ${ }^{16}$

The descriptions of daily life experienced by white male prisoners at Kroonstad, make it seem as if life for this category of prisoners was healthier inside the prison than out. A good example is a description of

15 See for example, Peté supra $\mathrm{n} 1$

16 The words used were: "Op Kroonstad, in die gevangenis vir blanke mans, het $\mathrm{n}$ nuwe dag begin. Dis $05 \mathrm{~h} 00$ en dis nog ' $\mathrm{n}$ dag, nog $\mathrm{n}$ oneindiging van self ondersoek, selfbejammering, van discipline en stilstand, om weer jou sin vir waardes in oënskou to neem ... Halfsewe, met die geklingel van blikbord en mes nog in die ore en die behaaglikheid van 'n vol maag en warm lywe saam om $n$ eettafel staan hulle met strak gesigte in die eerste bleek strale van $n$ winteroggend, gereed vir die dagtaak wat moet help skaaf en voorberei vir die nuwe lewe - eendag ... [H] ande timmer, sweis, verf, buig en vorm - vyf ure lank. Halftwalf is dit etenstyd. Op 'n sentrale punt sluk en kou honderde monde gretig aan warm, gebalanseerde kos, rook $n$ kosbare sigaret, wissel begeertes en verlangens ... en stap na 
the wholesome prison diet, which was said to lower the usual health risks faced by the white population in general:

As a medical official recently explained: 'Improved diets incorporating greater quantities of fibre and fewer refined foods mean that white prisoners in South African goals are less likely to suffer from coronary heart disease, obesity and appendicitis than the rest of the white population. ${ }^{17}$

The list of indoor sports activities provided for white prisoners at Kroonstad reads more like the offerings made available at a sports oriented resort than a prison. The sports at Kroonstad included snooker, body building, darts, table tennis, squash, jukskei, boxing, card games and chess. ${ }^{18}$ The overarching theme which informed the descriptions in Die Volksblad of the white male prison experience, was that all aspects of their lives were focused on rehabilitation. Over and over again the articles in Die Volksblad emphasised treatment, rehabilitation and training as the central goal of imprisonment for this category of offenders, with the aim of producing a better "product" for society in general:

Although, of necessity, the treatment programmes of short and long term prisoners differ, they essentially amount to discouraging negative patterns of behaviour and strengthening positive socially acceptable forms of behaviour. It boils down to the development of self-discipline, constructive labour as a counter to idleness and the cultivation of a sense of responsibility. ${ }^{19}$

A possible reason for this is that, for politically conservative newspapers such as Die Volksblad, white male prisoners were still regarded as being part of the "white lager". Misguided they may be, but certainly not beyond salvation and eventual re-integration into white society. Of course, this somewhat romanticised view of white male prisoners as penitents engaged in a process of self-reflection and

werkplekke. Tot halfvyf. Dan is dit die lang, trae pad terug na die gevangenis ... Dan is die geleentheid daar vir ontspanning en rus. Mededinging in sport, kragte en vernuf meet, trofee en skilde verower - of net met $\mathrm{n}$ boek le, na musiek luister en orde prober kry in jouself en jou beperkte ongewing". See Die Volksblad (1980-09-23) 'Hier gaan dae traag en grou verby ...' 10.

17 The words used were: “Soos 'n mediese beampte onlangs gese het: 'Die beter dieet met meer veselstowwe en minder geraffineerde kos veroorsaak dat blanke gevangenes in Suid-Afrikaanse gevangenisse minder ly aan koronêre hartsiektes, oorgewig en blindedermontsteking as die res van die blanke bevolking"”. See Die Volksblad (1980-09-23) "n Beter produk gevorm vir gemeenskap' 13.

18 "Binnenshuise sport op Kroonstad bestaan uit onder meer snooker, liggaamsbou, veerpyltjies, tafeltennis, pluimbal, jukskei, boks, kaartspele en skaak". See Die Volksblad supra n 17 at 13.

19 The words used were: "Hoewel die behandelingsprogramme vir kort en langtermyngevangenis noodwendig verskil, behels dit essensieel vir alle gavangenis $n$ dekondisonering van negatiewe gedragspatrone en $n$ versterking van positiewe, sosiaal aanvaarbare gedrag. Dit kom neer op die ontwikkeling van selfdissipline, konstruktiewe arbeid as teenvoeter vir ledigheid en die aankweek van n verantwoordelikheidsin". See Die Volksblad supra $\mathrm{n} 17$ at 13 . 
rehabilitation may not have been shared by the broader "white" ruling class. Nevertheless, it is submitted that the views expressed in these articles provides an interesting insight into the attitudes of a least one faction of the white community at this time, ie those conservatively minded members of that community who tended to form the core of the apartheid government's political support base. The political and ideological assumptions embedded within the Volksblad articles provide important clues to the manner in which this important faction of the white ruling class conceptualised the fundamental nature and purpose of punishment. It may be argued that, consciously or unconsciously, they viewed the nature and purpose of punishment in a schizophrenic manner, shifting between diametrically opposed ways of looking at the issue, depending upon whether they had in mind the punishment of "white" offenders or "non-white" offenders. This bifurcation in attitude, dependent upon the race of the offender concerned, harks back to colonial times, when the colonial elite - particularly towards the end of the colonial period in Natal - conceived of the punishment of white and black offenders in completely separate terms. ${ }^{20}$

\section{Demons and Gangsters - The Explosion of Interest in Prison Gangs}

Although South African prison gangs have a long and rich history, it is interesting to note that public discourse on the activities of prison gangs is largely absent during colonial times, at least in so far as the point of historical comparison in this article - the discourse surrounding the penal system of colonial Natal - is concerned. Of course, penal discourse in colonial Natal had its share of designated "demons", but these were defined in terms of racist colonial conceptions of the "brutal" and "savage" nature of the colony's indigenous inhabitants in general, rather than in terms of the activities of prison gangs in particular. In the minds of Natal's white colonists, black offenders in general were "childlike savages", possessed of natures which were brutal as well as childishly immature. They needed to be punished with sufficient severity so as to deter the "brutal savage", as well as in a manner which provided simple and direct guidance to the "childlike Native". For this reason, corporal punishment with the dreaded "cat o' nine tails" was regarded as a particularly suitable form of punishment for black offenders in colonial Natal, so much so that the practice became known as the "cult of the Cat". Much has been written on the ideology behind corporal punishment during colonial times, and need not be repeated here. ${ }^{21}$ For the purposes of this article it is sufficient to point out that, within the

20 See for example, Peté supra n 5; Peté \& Devenish supra $n 6$.

21 See in general, Peté ibid; Peté \& Devenish ibid; Crocker \& Peté 'Letting Go of the Lash: The Extraordinary Tenacity and Prolonged Decline of Judicial Corporal Punishment in Britain and its Former Colonies in Africa (Part 1)' 2007 Obiter 271-290; Crocker \& Peté 'Letting Go of the Lash: The Extraordinary Tenacity and Prolonged Decline of Judicial Corporal 
penal discourse of the 1980s, the position of the "brutal savage" or "demon" - what Stanley Cohen would refer to as a "folk devil"22 - has been assumed largely by the figure of the prison gangster, a member of one of South Africa's notoriously violent "numbers gangs". 23

The 1980s were a particularly important decade from the perspective of public discourse on the issue of prison gangs. Public interest in the topic was ignited by the publication of a particularly fascinating study on South African prison gangs and their bizarre history. The study was conducted at the University of Cape Town's Institute of Criminology by an anti-apartheid activist and former head of the National Union of South African Students, Nicholas 'Fink' Haysom. It was entitled "Towards an Understanding of Prison Gangs" and the shocking details it revealed about the origins and activities of South African prison gangs were seized upon by the public media. ${ }^{24}$ Publicity around the details revealed in this study was to mark the beginning of period of intense public fascination with these gangs, which continued into the post-apartheid period.

A good example of the public furore, ignited by Haysom's study, may be found in a number of newspaper articles published in June 1981, when the Weekend Argus carried no less than three reports focusing on various aspects of Haysom's study. The following provocative headlines were used: "It's 'boere' v 'bandiete' in SA jails", "Biblical origin of 28 gang" and "When the 'kring' says kill”. ${ }^{25}$ Details of the bizarre history and entrenched nature of the "numbers gangs", which had been operating in South African prisons since the late nineteenth century, as well as the extent of their power and brutality of their practices, must have come as a shock to members of the South African public, particularly the sheltered (mainly white) middle class. For example the following are extracts from the initial reports on Haysom's study carried by the Weekend Argus:

Prison gangs have created elaborate alternative societies. They have a structure, ranking and a discipline code maintained by an overall governing body - the 'kring'. Each gang has its oral history and has its uniform, tattoos, flags, salutes and other military paraphernalia. In each gang, decisions must be made by the proper procedure. For example, a 28 Circle decision to kill a prisoner must be taken by a full 'kring' and the 'judge' must sign the death warrant ... Prison officials say it is nearly impossible to prevent a murder once the decision has been taken. Inmates who have reported to the authorities that the finger has been pointed at them may be killed before the authorities

Punishment in Britain and its Former Colonies in Africa (Part 2)' 2007 Obiter 465-501.

22 Cohen Folk Devils and Moral Panics - The Creation of the Mods and the Rockers (1973).

23 For a contemporary account of life in one of the prison "numbers gangs", see Steinberg The Number - One Man's Search for Identity in the Cape Underworld and Prison Gangs (2005).

24 Haysom 'Towards an Understanding of Prison Gangs' 1981 UCT, Institute of Criminology.

25 See Weekend Argus (1981-06-20) 'When the “kring” says kill’ 15. 
take steps to protect them. A prisoner may attempt suicide rather than be confined in a cell with hostile gangsters, aware that he might endure months of nerve-racking tension before he might be killed. Murders are extremely brutal. Usually, the victim is strangled with a belt, or has his throat cut, or is eviscerated and his intestines removed and played with. A victim may receive numerous stab wounds and be left to die. ${ }^{26}$

Around two weeks after the above report, Haysom's study was, once again, the subject of a detailed report in the national media. The newspaper concerned was the Sunday Express, which discussed the disturbing conclusions set out in Haysom's study. Among the details published were the following:

In the paper, Mr Haysom asks who really controls South Africa's prisons. 'If many witnesses are reluctant to appear in the Supreme Court and if some State witnesses are murdered after they have given evidence, the question arises as to who actually does wield power in the prisons. If gang members would rather face the gallows than refuse to participate in murders that can only be described as suicide missions, does it not seem that there are two authority systems operating in the prisons?' ... 'The most notable feature of South African prison gangs is that they are nationwide. While their potency and membership fluctuates from prison to prison, the gangs boast, and with justification, that they have brothers in every prison. It is this fact that gives the gangs tremendous power. In essence this means that no prisoner is beyond their reach. A State witness in a trial will, they claim, never escape their vengeance ....27

After a further two weeks, the highlights of Haysom's study were, yet again and in similar terms, set out and commented upon in a detailed report in the South African media. The newspaper concerned was the Daily Dispatch, which ended its report by congratulating Haysom on his study and calling upon the government to act. ${ }^{28}$ Just over a week later, the Afrikaans press in the form of Die Burger picked up on the story and set out Haysom's findings in a detailed report. It began its report by stating that the contents of Haysom's study bordered on the incredible, and pointed to Haysom's assertion that it was almost impossible for the prison authorities to prevent the murder of an inmate sentenced to death by a prison gang. ${ }^{29}$

The publicity around Haysom's study seems to have caused an upsurge of interest within the media on the issue of South African prison gangs and their gruesome activities. For example, on 25 June 1981, Die Oosterlig reported that, over the previous four years, the Supreme (now High) Court in Port Elizabeth had sentenced eighteen persons, who were all members of one or other prison gang, to death for their involvement in seven prison murders. A further five prisoners were on trial for a similar prison murder in the St Albans prison. After describing the

26 Ibid

27 Sunday Express (1981-07-05) 'Gangs rule with iron fists in SA's prisons' 11

28 Daily Dispatch (1981-07-20) 'Murder gangs in SA's jails' 12.

29 Die Burger (1981-07-28) 'Wrede moorde in tronke' 6. 
gruesome nature of these murders, which involved the use of razor blades and sharpened spoons, the newspaper claimed that the motives for the murders were, in most cases, related to conflict between various prison gangs. ${ }^{30}$ The following month, it was reported that three of the five prisoners who had been standing trial for the St Albans prison murder had been found guilty. Under the headline "Prison horror", the Eastern Province Herald reported the facts of this shocking case inter alia as follows:

A man was held down by his feet and a belt was used to choke him. Then his throat was cut with a razor blade. The man, a convict, had been in the care of the State at the time. But the State was unable to protect him in the cell he shared with 25 other men in Port Elizabeth on the night of August 22 last year. The power of a prison gang was more effective ... The evidence in this case was as repulsive as it was bizarre. One of the convicted men said the gang held a 'court' and decided a man in the cell should be put to death. It was left to the designated killers to choose the victim. There was testimony about homosexual rape in terms suggesting habitual practice. Then there was a description of a deliberate killing. Nobody intervened. ${ }^{31}$

A further result of all the publicity on the issue of prison gangs, seems to have been that the authorities were spurred into action. In October 1982, it was announced that the Prisons Service had commissioned the Human Sciences Research Council to conduct extensive research into the activities of prison gangs in South Africa. 32

Perhaps because of its bizarre and shocking content, Nicholas Haysom's 1981 study of South African prison gangs continued to enjoy an extraordinarily long "shelf-life" as far as the press was concerned. For example, on 16 October 1983 under the sensational headline "Inside the Circle of Death", the Sunday Express carried an in-depth report on South African prison gangs, based very largely on the details set out in Haysom's study. The report detailed, inter alia, the brutal murder in May 1978 of Mleleki Dhlamini, by members of the 26 and 28 gangs in the Leeuwkop prison. Dhlamini's death was described in the following lurid and shocking terms:

After Dhlamini had been sentenced in 'The Circle' or 'Kring', his executioners held him down, slit his stomach open with a razor blade, beginning a slow, merciless murder in a dark communal maximum security cell shared by 41 prisoners. He cried out for mercy - to be killed quickly. But his executioners took their time with tortures too gruesome to relate. Eventually, a belt was tied around his neck and he was hanged over the bars of the cell door. ${ }^{33}$

Yet further articles, summarising various sections of Nicholas Haysom's 1981 study, appeared in the press on 5 November 1983, 13

30 Die Oosterlig (1981-06-25) 'Bendes pleeg moorde in nag - 18 in PE tronke kry doodstraf in 4 j' 11.

31 Eastern Province Herald (1981-07-14) 'Prison horror' 6.

32 Beeld (1982-10-29) 'Tronk-bendes ondersoek' 12; Hoofstad (1982-10-29) 'RGN kyk op versoek na tronk-bendes' 11.

33 Sunday Express (1983-10-16) 'Inside the circle of death' 19 
April 1984 and 14 April 1984 respectively. The first article appeared in the Weekend Post under the headline "SA's notorious prison gangs date back to late 19th century"; the second, in The Cape Times, under the headline "A mechanism for control over lives"; and the third, in the Rand Daily Mail, under the headline "Rituals and edicts of prison gang societies". 34

In addition to the articles essentially re-cycling the results of Haysom's seminal study, South African newspapers continued to report on the activities of prison gangs throughout the period under examination. For example, in June 1983 reports of gang warfare at Leeuwkop prison emerged in the media. The reports emerged as the result of evidence led at the trial of nineteen prisoners at the Johannesburg Magistrate's Court. The prisoners on trial were members of the "Big Five" prison gang and were alleged to have assaulted a member of the rival " 28 " gang, a certain Jeremiah Maseko, who died in a coma two months later. A witness to the incident, Simon Makau, appeared to be terrified of testifying against the accused in the matter and, according to a report in The Star, he told the magistrate, Mr IJJ Luther, that: "If I point the men out, I will be selling my life because they will kill me when we return to Leeuwkop ... There is no safety for prisoners in that jail". 35 The report went on to state that: "A trembling Makau later reluctantly identified the men and told Mr Luther: 'I have signed my death warrant and have taken my soul out of my life". 36 These words portray in poignant fashion, the terrifying power exercised by prison gangs over the lives of inmates at this time.

In October 1983, the Afrikaans language newspaper Rapport published an article detailing prison life at the Brandvlei maximum security prison. ${ }^{37}$ One of its reporters had been permitted to interview inmates at Brandvlei and had asked them about the extent of gang

34 Weekend Post (1983-11-05) 'SA's notorious prison gangs date back to late 19th century' 15; The Cape Times (1984-04-13) 'A mechanism for control over lives' 15; Rand Daily Mail (1984-04-14) 'Rituals and edicts of prison gang societies' 6.

35 The Star (1983-06-18) 'Tale of gang warfare inside prison walls' 4.

36 Ibid.

37 This was one of a series of articles published by Rapport in October 1983. The newspaper claimed that the Commissioner of Prisons, LieutenantGeneral JF Otto, had specifically lifted the veil of secrecy so that the newspaper could write a series of "no-holds-barred" articles on South African prisons (see Rapport (1983-10-16) 'Unieke reeks oor SA gevangenisse begin - Agter tronk deure - Ons kon oral instap ...' 1). Under the headline 'Behind Prison Doors - We had total access', the newspaper made much of the fact that it had been afforded unhindered access to all South African prisons (see Rapport (1983-10-16) supra); it labeled this fact as "unique" in South African newspaper history (the words used were: "iets unieks in koerantgeskiedenis"; see Rapport (1983-10-16) supra) The newspaper gushed (ironically when viewed from the perspective of postapartheid South Africa) that it had not even been expected to submit its reports to the prison authorities before publication and was able to make its own observations (the Afrikaans words used were: "Daar is nie eens van Rapport verwag om ons berigte voor publikasie voor te le nie. Ons kon ons eie waarnemings maak" (see Rapport (1983-10-16) supra). Although 
activities in the prison. After speaking to several inmates, including a certain inmate named "Samma" who was said to carry the rank of a "fighting general [veggeneraal]" in one of the prison gangs, the reporter came to the conclusion that much of life in the prison revolved around sex. He explained as follows in his report:

One gets the impression that each man has his own 'moffie' or 'laaitie'. Sodomy is rife. Samma confirmed that most trouble revolves around 'moffies'. Although each man usually has his own 'moffie', the prison also has its quota of 'whores'. They are the people who do not belong to one 'man', but shop around. It is around them that all hell often breaks loose. It is the duty of each man to look after his 'laaitie' and to care for him. A bit of oil for his hair or an extra helping of food is important to maintain the relationship. ${ }^{38}$

In April 1984, a certain Mr James D Petersen, who was said to be a "General" in the 26 prison gang, revealed to the press the story of his involvement with the gang. Petersen had been released from Brandvlei in February 1984, and seems to have been motivated to tell his story due to the fact that he had undergone a religious conversion. ${ }^{39}$ By revealing details of gang activities and practices to the press, Petersen was clearly taking a great risk. The Rand Daily Mail described Petersen's story as "an at times bizarre and brutal account of organised gangsterism behind bars". 40 According to the Rand Daily Mail, both Petersen's tattoos (six stars and a law book on each shoulder) and his knowledge of the structure and policies of South African prison gangs, marked him out as a "General" of the 26 prison gang. According to the report, Petersen had been known in prison by the nickname "Kettings [Chains]". Among his revelations to the Rand Daily Mail, Petersen stated that, in 1974, there

Rapport may have been playing up the significance of its series of articles for dramatic effect, the tone of the comments which accompanied the newspaper's announcement of the series, indicates clearly that access to South African prisons by newspaper reporters was not a common occurrence at this time. The newspaper stated that the Prison Service had allowed its reporters to walk into any prison in South Africa unannounced and without prior warning. It warned its readers that they might be shocked at what went on in prisons, but pointed out that the series was a "warts and all" expose. The Afrikaans words used were: "Ons skryf in die reeks kaalkop daaroor"; see Rapport (1983-10-16) supra. Significantly, the newspaper claimed that this indicated that there was nothing that the Prison Service wished to hide.

38 “' $n$ Mens kry die indruk dat elke man sy eie 'moffie' of 'laaitie' het. Sodomie vier hoogty. Samma het bevestig dat die meeste moeilikheid om moffies gaan. Hoewel elke man gewoonlik sy eie 'moffie' het, het die gevangenis ook sy kwota 'hoere'. Hulle is die mense wat nie een 'man' het nie, maar rondsmous. Rondom hulle bars alle hel dikwels los. Elke man maak dit sy taak om sy 'laaitie' op te pas en mooi na hom te kyk. 'n Olietjie vir die hare of ' $n$ extra skoepie is belangrik in die verhouding." Rapport (1983-10-16) 'Bendes het eie straf' 9.

39 Petersen was quoted as stating that: "Gang fights have got to stop no one is benefitting from them. I would like to help achieve this now that I have given myself over to the Lord". See Rand Daily Mail (1984-04-14) 'A stark, sordid underworld behind bars' 6.

40 Rand Daily Mail supra n 39 at 6. 
had been around 500 members of the 26 prison gang in the Brandvlei prison. He told the newspaper that he "didn't like the way the 28s continually practiced homosexuality or their favourite method of killing other prisoners - by using poison". ${ }^{41}$ Petersen maintained that it was established practice for members of the 28 prison gang to force young prisoners "to act as 'moffies'". He stated further that: "These boys have got very little choice. Gang rapes still take place in every prison in South Africa - the authorities will never be able to stamp this out". 42

The South African Prisons Service decided to respond publicly to the shocking claims made by Petersen in his interview with the Rand Daily Mail. A spokesman for the Prisons Service, Brigadier HJ Botha, rejected Petersen's contention that members of the 28 prison gang used poison to kill their victims, stating that "no record could be found of cases where prisoners were killed by other prisoners by using poison". ${ }^{43}$ Botha also stated that: "In South African prisons ... gangs are not tolerated and steps are continually taken to combat their formation and functioning". ${ }^{44} \mathrm{He}$ also spoke of the existence of a "prison milieu" which "promotes the cultivation of those characteristics that are necessary for a prisoner's successful reintegration into society as a law-abiding citizen". ${ }^{45}$ Whatever the accuracy of Petersen's statements to the Rand Daily Mail, in light of the significant degree of evidence that had been put forward over the years of a long-established and thriving gang culture within South African prisons, the general thrust of the statements by Brigadier Botha, on behalf of the South African Prisons Service, smacks of extreme naïveté or a wilful disregard of reality. One indication that South African prisons were clearly extraordinarily violent places during the period under examination, was the number of unnatural deaths which occurred within the penal system. For example, in March 1984 in answer to a question in Parliament, the Minister of Justice, Mr Kobie Coetzee, revealed that 260 deaths had been reported in South African prisons in 1983. Of these, 76 deaths had been classified as "unnatural". The reason given for the vast majority of these unnatural deaths was "assault by fellow prisoners". It was revealed that 57 "black prisoners" and 16 "coloured prisoners" had died in this way. ${ }^{46}$ These shocking statistics reveal something of the extent of violent activity in South African prisons at this time.

In May 1984, widespread publicity was given to the report of the Van Dam Committee of Enquiry. This committee had been set up at the insistence of the Minister of Justice and Prisons, Kobie Coetsee, in order to investigate a series of violent incidents which had occurred within the

41 Ibid.

42 Ibid.

43 Daily Dispatch (1984-04-13) 'SA Prisons to combat gangs' 17. See also Rand Daily Mail ibid.

44 Daily Dispatch idem 17. See also Rand Daily Mail ibid.

45 The Cape Times (1984-04-13) 'Steps taken to stop gangs in jails' 15. See also Rand Daily Mail ibid.

46 The Citizen (1984-03-06) 'Prison deaths top 250' 4 
Barberton prison complex between 29 December 1982 and 30 September 1983. ${ }^{47}$ No fewer than twelve prisoners had died as a result of violence during this period. ${ }^{48}$ One of the main findings of the committee was that the activities of prison gangs, which it described as "horrifying", had played a central role in the violence. ${ }^{49}$ The extent of the publicity given to the activities of Barberton's prison gangs was such that it is impossible to summarise all the reports in a short article such as this. ${ }^{50}$ The following two extracts from articles published in the mainstream media in May 1984, however, provide a flavour of the type of press coverage given to prison gangs at this time. Under the headline "Report details brutal prison gangs", the Rand Daily Mail stated as follows:

Alarming evidence of the existence of violent gangs in South African prisons has been uncovered by the Van Dam Inquiry into the Barberton prisons. It said the gangs, which were 'very strong', were mainly found in maximum security prisons. The committee found evidence of violence, assaults, murders, homosexuality and gangs specialising in escapes ... The committee described as 'frightening' the 'merciless cruelty' of the gangs and their members who could, in exceptional circumstances, take action against prison personnel. Often gangs sentenced members to death for the flimsiest of reasons and the death penalty was carried out with a variety of brutal methods. ${ }^{51}$

On the same day as the above report was published, another mainstream South African newspaper, The Star, provided its readers with the following shocking details about the activities of Barberton's prison gangs:

Cold-blooded murders were committed for rumours or transgressions of the gang codes. Innocent people were often assaulted simply as a show of force or to take revenge for a misdemeanour. Many weapons, including knives, were made in prison to use against prisoners. A favourite weapon was the heavy metal mugs in which prisoners received coffee or tea. Tied to a halfmetre belt of towel, they formed a dangerous weapon. Six gangs were identified in the prison. In some of them, sodomy was prevalent and younger members were known as 'wyfies'. Members of such a gang did not hesitate to

47 See Peté 'Apartheid's Alcatraz - The Barberton prison complex during the early 1980s' (forthcoming).

48 Sunday Express (1984-02-05) 'Minister still to see prison report' 11. See also Die Burger (1984-05-17) 'Tronkbendes was agter geweld' 7.

49 The Argus (1984-05-17) 'Gangs' role in prison riots "horrifying"' 4.

50 The headlines of various articles published at this time reflect the extent of public concern about the activities of Barberton's prison gangs. For example: Die Vaderland (1984-05-17) 'Bendes in tronke moet vasgevat word [Prison gangs must be curbed]' 2; Rand Daily Mail (1984-05-17) 'Report details brutal prison gangs' 11; Die Burger supra n 48 at 7; The Argus supra $\mathrm{n}$ 49 at 4; The Star (1984-05-17) 'New strategy on prison gangs "vital"' 1; The Star (1984-05-17) 'Horror gangs a key factor in prison riots' 5; The Star (1984-05-19) 'Prison gangs: the grim truth' 11.

51 Rand Daily Mail (1984-05-17) supra n 50 at 11 . See also Die Vaderland supra n 50 at 2 . 
murder if members of their own or of other gangs interfered with their 'wyfies' ... 52

The following month, in June 1984, as part of a series of articles on "The Killer Gangs", the Eastern Province Herald published a report dealing with prison gangs in the Port Elizabeth area. According to the report, since 1978 no fewer than 22 prison gang members had been sentenced to death in Port Elizabeth for murders committed behind bars. Most prison gang activity was said to take place at the St Albans prison in Port Elizabeth. The report emphasised the brutality of the prison gangs, citing a former convict who had risen to the rank of captain - a senior position in the 28 prison gang at St Albans. In the words of the report:

Nobody gets to the top of a prison gang without spilling blood. 'If you want to become a leader you have to be willing to kill. You must be bad, worse than the next man'. Only ruthlessness can ensure total obedience by others in the gang. A soldier ordered to kill a cell-mate will do so without hesitation, knowing his own throat would be slit if he refused. Seldom will convicts before court implicate a gang leader in the killing. That also means certain death. 'It is a big thing to smuggle dagga into jail but it is not unusual. And we make knives from all kinds of things', said the former captain of the 28s. 'If we want to punish somebody without stabbing him, we would put a belt through the ear of a tin mug and beat him unconscious with it'. ${ }^{53}$

The Eastern Province Herald also described, in grisly detail, a number of murders which had been committed by prison gangs in the Port Elizabeth area. According to the newspaper, these accounts were "based on reports of murder trials held in Port Elizabeth". 54 A good example of the spine chilling detail to which the readers of the Eastern Province Herald were exposed, concerned the murder of a certain Simon Joseph on 22 August 1980 in the North End Prison, by members of the 28 gang. The murder was described as follows:

Two of the men were sitting alongside Joseph and a third was on his haunches near Joseph's feet. Suddenly this man jumped forward and threw a belt around Joseph's neck. One man fell across his legs, pinning Joseph to the floor. Two others held his arms. Then his throat was hacked open with a razor blade. Blood spurted everywhere, covering Joseph's assailants, the floor and walls. His throat gaped from ear to ear... From across the cell the 28's general watched. When the body lay still the general got up and crossed to a member of the 27 gang. 'We have taken a head,' he said. ${ }^{55}$

The South African Prisons Service responded to these reports in the Eastern Province Herald with a bland statement to the effect that gangs were not tolerated in South African prisons and that steps were continually taken to combat their function and ability to function. The Chief Liaison Officer of the South African Prison Services, Brigadier HJ Botha, stated that the prisons service was "deeply concerned about any

52 The Star (1984-05-17) 'Horror gangs a key factor in prison riots' 5.

53 Eastern Province Herald (1984-06-21) 'It's murder behind bars' 10.

54 Idem 15.

55 Ibid. 
incident of a violent nature" and that the service strove constantly "through research and practical experience, to eliminate the phenomenon of gangs in prison, or at least to contain it to the extent that it can be neutralised effectively". ${ }^{56}$ What is revealed by the examination of the public discourse on prison gangs set out above, however, is that this problem was both severe as well as deeply entrenched within South Africa's penal system. Due to the extensive publicity surrounding the activities of prison gangs during the period in question, it seems clear that no informed South African could honestly deny knowledge of either the severity or extent of the problem. This makes the "formulaic" responses of the South African Prison Services seem out of touch with the reality of the problem. The discourse consists of one shock revelation after the other, with the problem remaining firmly in place from one year to the next. In fact, the theme of extreme violence caused by entrenched prison gangs, was to extend way beyond the 1980s and well into the post-apartheid period. ${ }^{57}$ The sadistic and violent prison gangster - the "demon" or "folk devil" who could not be safely contained - was to remain a prominent figure within South African penal discourse for many years to come.

To end this section, two brief notes on the brutality of the South African penal system in response to those perceived as "demons". The first concerns the "caging" of dangerous prisoners. In October 1983, a reporter and photographer from the Afrikaans newspaper Rapport visited the maximum security prison situated at Brandvlei near Worcester in the Boland. ${ }^{58}$ At the time, the prison contained 664 dangerous prisoners and was known as the Barberton of the Cape. ${ }^{59}$ What the reporter and photographer saw on their visit is reminiscent of what one might have seen during a visit to a prison in colonial Natal during the nineteenth century. ${ }^{60}$ According to an article which appeared in Rapport following the visit, a series of wire cages, approximately two metres square, had been erected in an enclosed courtyard at the prison. The courtyard was

56 Idem 2.

57 See in general, Peté 'The Politics of Imprisonment in the Aftermath of South Africa's First Democratic Election' 1998 South African Journal of Criminal Justice 51-83; Peté 'The Good the Bad and the Warehoused - The Politics of Imprisonment During the Run-up to South Africa's Second Democratic Election' 2000 South African Journal of Criminal Justice 1-56; Peté 'No Reason to Celebrate: Imprisonment in the Aftermath of South Africa's Second Democratic Election' (forthcoming).

58 This was for the purpose of obtaining material for a series of "first hand" articles on South African prisons. See n 37 for a full description of the manner in which this series of articles was conceived and brought to fruition.

59 The Barberton Maximum Security Prison was notorious for housing the most dangerous prisoners within the South African penal system at that time. See Peté 'Hell on Earth - The Barberton Prison Complex in the Early 1980s' (forthcoming')

60 See in general, Peté 'Falling on Stony Ground: Importing the Penal Practices of Europe into the Prisons of Colonial Natal (Part 1)' 2006 Fundamina 100112; and Peté 'Falling on Stony Ground: Importing the Penal Practices of Europe into the Prisons of Colonial Natal (Part 2)' 2007 Fundamina 111-125. 
open to the elements and each cage contained a convict busy breaking stones with a hammer. The reporter expressed his amazement at witnessing this scene by stating that, for the first time in his life, he realised that, just as the convicts of old had done, South African prisoners at Brandvlei still engaged in stone-breaking. ${ }^{61}$ The convicts' food was passed to them in bowls which was pushed underneath the gates to the wire cages. The spoons with which they ate had no handles, in order to avoid the possibility that they could be turned into weapons. ${ }^{62}$ The report pointed out that the stone breakers were all "brown or black" ie there were no white prisoners among them. According to the report, none of the prisoners complained about being locked in the cages to perform stone breaking, since it was preferable to being locked up in a single cell day and night. The prisoners also told the reporter that they felt safe in the cages, where they did not have to be on the lookout for other violent prisoners. ${ }^{63}$ The prison authorities informed Rapport that this was a pilot project aimed only at the most dangerous prisoners within the penal system. At that stage, authorities believed that the project had been successful in all respects. ${ }^{64}$ There were "single cages", which each measured approximately two square metres, as well as larger "group cages". Cages had been constructed at two prisons in the Cape Brandvlei prison in the Boland and Victor Verster prison in Paarl. Brandvlei had 330 single cages as well as a number of group cages which could accommodate 70 prisoners, while Victor Verster had 96 single cages, with a further 96 being built. It was also revealed that there were group cages at the Leeuwkop prison near Johannesburg which could

61 "Vir die eerste keer besef jy dat mense vandag nog soos die bandiete van ouds in 'n gevangenis letterlik klippe kap." See Rapport (1983-10-16) 'Elke man in sy kampie - en hy kap klippe!' 9.

62 In relation to the issue of "homemade" weapons, another article in the same edition of Rapport, spoke of the ingenious ways in which prisoners manufactured weapons using items such as nails, spoons, tin plates and pieces of metal pipe. The article also described the ingenious methods employed by prisoners to conceal weapons. According to the article, on one occasion the internal search of a certain prisoner at Brandvlei, had discovered no fewer than three knives concealed in the man's rectum. The reporter summed up his astonishment as follows: "One must see it to believe what sorts of objects prisoners are capable of secreting in their bodies. Those 'suitcases [soetkyste]' as they are known in prison slang, are capable of concealing virtually anything" (the Afrikaans words used were: "'n Mens moet sien om te glo wat die gevangenis alles in hul lywe kan opdruk. Daardie 'soetkyste', soos dit in gevangenistaal genoem word, verberg feitlik enigiets"; See Rapport (1983-10-16) 'Alles word wapens' 10). In a comment with slightly racist overtones, the article mentioned that white prisoners were even more ingenious in manufacturing weapons. It cited the example of a weapon that had been manufactured at the Zonderwater prison near Cullinan, which looked like a normal pen, but could fire .22 rounds. See Rapport (1983-10-16) 'Alles word wapens' 10.

63 Rapport supra $\mathrm{n} 61$ at 9.

64 In view of the fact that stone-breaking was a common form of hard labour for convicts in colonial times, one gets a strong sense that the apartheid prison authorities, who came up with this idea, were looking "back to the future". For example, see Peté "Penal Labour in Colonial Natal - The Fine Line between Convicts and Labourers' 2008 Fundamina 66 77-82 
accommodate 200 prisoners. In view of the type of work being performed by these "caged" prisoners - ie stone-breaking - an ironic twist to the article in Rapport was the assurance by the prison authorities that, as far as practically possible, attention was focused on opportunities for training, and that prison labour was designed to be productive in nature and as constructive as possible. ${ }^{65}$ Significantly, although reporters may have expressed surprise at the sight of caged prisoners performing stone breaking, there was no real critique of the penal system in the articles examined above. It would seem that, during the period under examination, South Africans were inured to the brutality of the apartheid system in general and the penal system in particular.

A final note to end this section, concerns the cruel manner in which the death penalty was carried out at this time, further illustrating the brutality of the South African penal system at this time. In July 1981, a disturbing report appeared in The Cape Times concerning the manner in which four death row prisoners had been executed. The report started with the following firm denunciation of the death penalty: "Judicial murder, in the form of hanging, is still one of the more barbaric aspects of South African society, one that disposes of more than a hundred human beings a year without noticeable effect on the ever-increasing homicide rate". ${ }^{66}$ It then went on to explain that four death row prisoners had been tear gassed when they refused to leave their cell and be led to the gallows. After the tear gassing, the men were dragged out of the cell and hanged. The Prison Service stated that it could not give an expert opinion on whether the men were still under the influence of tear gas when they were hanged. The Cape Times commented on the response of the Prison Service as follows:

The very fact that the prison authorities cannot be sure is a tacit admission that the men were not allowed to recover completely from the gassing before being plunged into eternity. The execution should have been delayed, and the men sedated. That at least would have restored to them some human dignity before being deprived of life. 67

Another example of the brutality that is encompassed in the death penalty, is a poignant report which appeared in Die Volksblad in April 1983, concerning the manner in which prisoners on death row reacted to an approaching execution. The main focus of the report was on the well-known Afrikaans poet Breyten Breytenbach, who had served a period of seven years imprisonment. According to the report, one of Breytenbach's most prominent recollections of his time in prison was the way in which black prisoners used to sing before they were put to death. When a black inmate on death row was told of the date on which his sentence would be carried out, he would begin to sing. All his fellow black prisoners on death row would then sing along with him, almost constantly, for the week which preceded the execution. According to the

65 Rapport (1983-10-16) 'Kampies hou hulle uit mekaar' 8

66 See The Cape Times (1981-07-22) 'Gassed and hanged' 12.

67 Ibid. 
report, the prisoners sang Christian songs, particularly psalms, but also blues, as well as the hit songs of Myriam Makeba. ${ }^{68}$ The death penalty was widely used in South Africa at this time. In October 1984, a brief report in The Cape Times mentioned that, during 1983, about 100 people had been executed in South Africa for non-political offences and three for treason. ${ }^{69}$

\section{Conclusion}

In Part One of the article, two "characters" who formed part of the story told by penal discourse in the first half of the 1980s have been examined - the white male prisoner (the "penitent") and the prison gangster (the "demon"). It has been shown that these two characters occupied completely different conceptual spaces within the penal ideology of the time. White male prisoners, segregated in their own prison, were seen as "penitents" undergoing a period of enforced self-reflection and rehabilitation, which would enable them to be reabsorbed into white society. Prison gangsters were the "demons" of the story - cruel, sadistic, violent and savage - who generated intense anxiety on the part of the white middle class and were surrounded by a discourse of retributive punishment. In each case, it has been shown that there are "historical resonances" which serve to cast light on the penal discourse surrounding each of these categories of prisoner in the early 1980s. The fact that clear historical parallels can be drawn between penal debates which took place in colonial Natal, and those which took place during the height of apartheid in the early 1980s, is significant. It shows that ideological attitudes are deeply rooted and are able to endure over many decades. Prison reform is not simply a matter of bringing about physical changes within the penal system, but also about understanding and transforming these deeply rooted ideological attitudes. Part two of the article will deal with another two characters in penal drama of the early 1980s, namely, "Fallen Angels" (white female prisoners) and "innocents" (children).

68 See Die Volksblad (1983-04-25) 'Digter se onthulling oor werk in selle' 13.

69 See The Cape Times (1984-10-24) 'Amnesty puts SA in report' 19. 